\title{
The efficacy of ferrous bisglycinate and electrolytic iron as fortificants in bread in iron-deficient school children
}

\author{
Martha E. van Stuijvenberg ${ }^{1}$, Cornelius M. Smuts ${ }^{1}$, Petronella Wolmarans ${ }^{1}$, Carl J. Lombard ${ }^{2}$ \\ and Muhammad A. Dhansay ${ }^{1}$ \\ ${ }^{1}$ Nutritional Intervention Research Unit, Medical Research Council, PO Box 19070, Tygerberg 7505, South Africa \\ ${ }^{2}$ Biostatistics Unit, Medical Research Council, Cape Town, South Africa \\ (Received 11 May 2005 - Revised 6 September 2005 - Accepted 10 November 2005)
}

\begin{abstract}
Food fortification is an important long-term strategy for addressing micronutrient deficiencies. Finding the ideal Fe fortification compound, however, remains a challenge. In the present study the effect of ferrous bisglycinate as fortificant in brown bread was compared with that of electrolytic Fe among Fe-deficient school children in a randomised controlled trial. Children ( $n$ 160), aged $6-11$ years, with serum ferritin $<20 \mu g / 1$, were randomly assigned to one of three treatment categories: (i) standard unfortified bread; (ii) bread with electrolytic Fe as fortificant; and (iii) bread with ferrous bisglycinate as fortificant. Each child received four slices of bread (120 g) on school days, which supplied an average of 3.66 mg elemental Fe per intervention day for $137 \mathrm{~d}(2.52 \mathrm{mg} / \mathrm{d}$ for $75 \mathrm{~d}$ and $5.04 \mathrm{mg} / \mathrm{d}$ for $62 \mathrm{~d})$ over a period of 7.5 months. Hb, serum ferritin, serum Fe and transferrin saturation were measured at baseline and at the end of the intervention. Significant treatment effects were observed for $\mathrm{Hb}(P=0 \cdot 013)$, serum Fe $(P=0 \cdot 041)$ and transferrin saturation $(P=0.042)$ in the ferrous bisglycinate group, but not in the electrolytic Fe group. There were no significant intervention effects for serum ferritin in either treatment group. Overall, ferrous bisglycinate as Fe fortificant in brown bread performed better than electrolytic Fe in a group of Fe-deficient school children over a period of 7.5 months.
\end{abstract}

Iron fortification: Ferrous bisglycinate: Electrolytic iron: Fortified bread: School children

Fe deficiency is the most common nutritional deficiency in both the industrialised and developing worlds, affecting mostly infants, children, and women of childbearing age. The fortification of staple foods is an important recognised long-term strategy for addressing micronutrient deficiencies, including that of $\mathrm{Fe}$ (Cook \& Reusser, 1983; Hurrell, 1997). Finding the ideal Fe fortification compound, however, remains a challenge. Fe compounds that are water-soluble and have a high bioavailability tend to cause organoleptic changes in the food to be fortified. On the other hand, insoluble Fe compounds that do not cause sensory changes in the food vehicle, e.g. elemental Fe powders, are usually poorly absorbed (Hurrell, 2002). Ferrous sulfate has a high relative bioavailability and is used as the standard against which all other Fe compounds are measured (Hurrell, 1997). It is, however, a chemically reactive compound that can cause rancidity and unacceptable colour and flavour changes in fortified products which are stored for extended periods (Hurrell, 2002).

The bioavailability of elemental Fe powders can vary greatly, depending on particle size, surface area and solubility, as well as the manufacturing process (Swain et al. 2003). Electrolytic $\mathrm{Fe}$ (particle size $<45 \mu \mathrm{m}$ ) has a bioavailability $\sim 50 \%$ that of ferrous sulfate (Hurrell et al. 2002), and is currently the recommended $\mathrm{Fe}$ compound among elemental powders for the fortification of cereal products when the use of ferrous sulfate or ferrous fumarate is not viable (SUSTAIN, 2001a). Electrolytic $\mathrm{Fe}$ has also been selected as Fe fortificant in the South African national food fortification programme for the fortification of maize meal and wheat flour (Department of Health, 2003).

Cereal flours are often used as vehicles for micronutrient fortification, because they are widely consumed and are usually centrally processed. Unfortunately, the large amounts of phytic acid present in cereal flours can have a potent inhibitory effect on the absorption of Fe (Hallberg et al. 1989). One way of counteracting this inhibitory effect is to add an $\mathrm{Fe}$ absorption enhancer, such as ascorbic acid, to the fortified product (Siegenberg et al. 1991). Ascorbic acid, however, is easily oxidised, and expensive sophisticated packaging may be required to prevent its degradation during storage. It is also destroyed to a great extent during food preparation, and its use as enhancer in cereal flours is therefore not always feasible (Hurrell, 2002).

An alternative solution is to use an Fe fortificant in which the Fe is protected from the effects of absorption inhibitors, e.g. chelated Fe compounds, and thus eliminating the need for ascorbic acid. Ferrous bisglycinate is an amino acid chelate which is formed by the binding of two molecules of glycine to one $\mathrm{Fe}^{2+}$ atom (Allen, 2002), and has a bioavailability two to four times that of ferrous sulfate (Olivares et al. 1997; Bovell-Benjamin et al. 2000; Layrisse et al. 2000). Because of its relatively low interaction with food (Layrisse et al. 2000), it is also less likely to cause sensory changes in the food vehicle. Ferrous bisglycinate has been acknowledged by the US Food and Drug Administration as being Generally Regarded As Safe for use as Fe fortificant in foods (Jeppsen, 2001). 
To date, there are very few controlled trials establishing the efficacy of either electrolytic $\mathrm{Fe}$ or ferrous bisglycinate in human populations, and certainly no studies comparing the effect of electrolytic $\mathrm{Fe}$ with that of ferrous bisglycinate. The aim of the present study was to compare the effect of ferrous bisglycinate, used as a fortificant in brown bread, with the effect of electrolytic $\mathrm{Fe}$ on the $\mathrm{Fe}$ and $\mathrm{Hb}$ status of $\mathrm{Fe}$-deficient primaryschool children in a randomised controlled trial. Because response to an Fe intervention may be affected by the vitamin A status of a population (Van Stuijvenberg et al. 1997), serum retinol was also measured.

\section{Methods}

\section{Study population and design}

The study was conducted in the Northern Cape, South Africa, in a primary school that is $\sim 400 \mathrm{~km}$ from Cape Town and serves a community that is of low socio-economic status. Of the 482 grade 1-3 children who were screened, 161 children with serum ferritin concentrations $<20 \mu \mathrm{g} / \mathrm{l}$ were selected to take part in the study. One child with $\mathrm{Hb}<90 \mathrm{~g} / \mathrm{l}$ was, for ethical reasons, not randomised and referred to the local clinic for treatment (Fig. 1). Of the 160 children participating in the study, $71.9 \%$ were Fe-deficient (serum ferritin $<15 \mu \mathrm{g} / \mathrm{l}$ ), $7.5 \%$ anaemic $(\mathrm{Hb}<115 \mathrm{~g} / \mathrm{l})$ and less than $1 \%$ were vitamin A-deficient (serum retinol $<20 \mu \mathrm{g} / \mathrm{dl}$ ). Based on the serum ferritin results of a previous Fe fortification study in primary-school children (Van Stuijvenberg et al. 1999), it was calculated that if only children with low $\mathrm{Fe}$ stores were included in the study, and a common standard deviation of $15 \mu \mathrm{g} / \mathrm{l}$ for serum ferritin were assumed, a minimum sample size of forty-seven per group would be required to detect a difference in response in serum ferritin between the active and control groups, at a $5 \%$ significance level, with $80 \%$ power. The study was approved by the Ethics Committee of the South African Medical Research Council, and permission was obtained from the Northern Cape Department of Education and the headmaster of the school. Written informed consent was obtained from the parents or guardians of all participants.

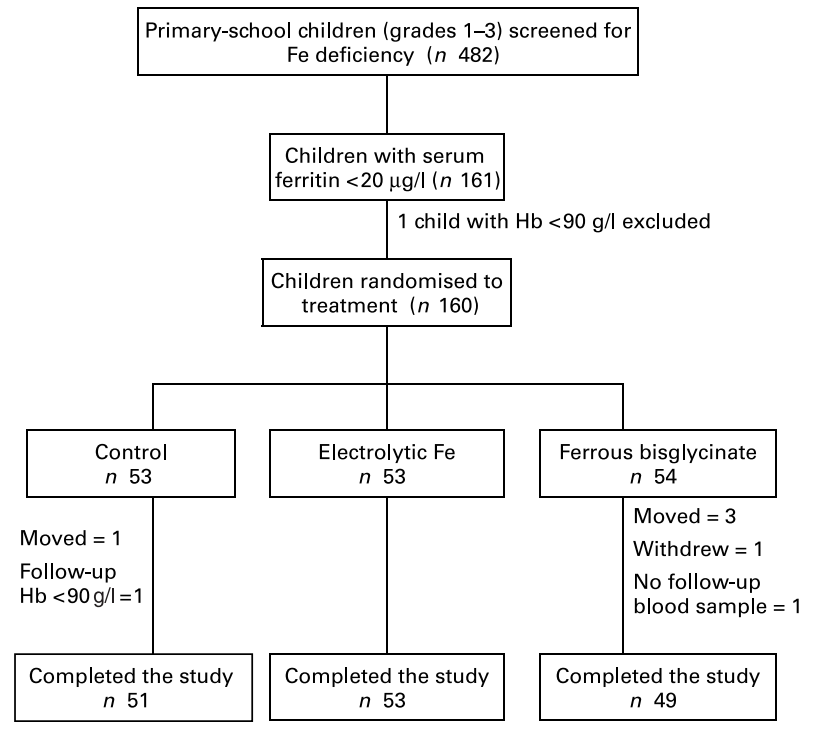

Fig. 1. Trial profile of the 7.5-month study.
Subjects were stratified by school grade and then randomly assigned to one of three groups, using random number tables. These groups were then randomly assigned to three different treatment categories: (i) a group receiving standard unfortified brown bread ( $n$ 53); (ii) a group receiving fortified brown bread using electrolytic $\mathrm{Fe}$ as the $\mathrm{Fe}$ fortificant ( $n$ 53); and (iii) a group receiving fortified brown bread using ferrous bisglycinate as Fe fortificant ( $n$ 54). The flour used in the bread had an extraction rate of $88 \%$. The three types of bread were similar in macronutrient composition, taste and appearance. To optimise compliance and to avoid cross-contamination between groups, the bread was delivered at the school in colour-coded (i.e. red, blue and yellow) containers; each loaf (pre-sliced by machine) was individually packed in a plastic sleeve and marked with the appropriate colour-coded sticker; sandwiches (spread with peanut butter and jam) were prepared at colour-coded tables and then distributed to the classrooms in smaller containers that were also colour-coded. Each child received four slices of bread $(120 \mathrm{~g})$ per school day over two meal periods. The bread was eaten under supervision of the class teacher and compliance was recorded daily, using colour-coded record sheets for the respective treatment groups. The bread provided as part of the study replaced the two slices of bread the children normally received via the school feeding system. Blood was drawn at baseline and again after 7.5 months of intervention. Children were dewormed 3 weeks prior to the baseline measurements being taken (500 mg mebendazole) and again 6 months later. All measurements were done blind and only the project leader was aware of group allocation (single blind study).

\section{Fortification}

Fortification of the wheat flour was done by an independent pharmaceutical manufacturing company (Zedchem (Pty) Ltd, Cape Town, South Africa). The flour was fortified with Fe, Zn, vitamin A, thiamine, riboflavin, niacin, pyridoxine and folic acid at levels that were in line with those prescribed by the national food fortification programme of the South African Department of Health (Table 1). At the time of the study, mandatory fortification of wheat flour had not yet come into effect. The four slices of fortified bread supplied $2.52 \mathrm{mg}$ elemental Fe (35 mg Fe/kg flour), in addition to Fe naturally present in bread. Due to time constraints, the study was limited to 7.5 months instead of the envisaged 12 months. In order to compensate for the shorter trial period, the level of fortificants in both $\mathrm{Fe}$ groups was doubled after the first 4.5 months of the trial (Table 1 ), and for the remaining 3 months the four slices of bread supplied $5.04 \mathrm{mg}$ of elemental $\mathrm{Fe}$, over and above the Fe naturally present in bread. No intervention took place during school holidays, on weekends or public holidays; the bread was provided for a total of 137 school days over the 7.5-month intervention period, supplying a total of $501.5 \mathrm{mg}$ elemental Fe: $2.52 \mathrm{mg} / \mathrm{d}$ for $75 \mathrm{~d}$ and $5.04 \mathrm{mg} / \mathrm{d}$ for $62 \mathrm{~d}$, i.e. an average of $3.66 \mathrm{mg}$ Fe per intervention day. The electrolytic Fe (particle size $<45 \mu \mathrm{m} ; 325 \mathrm{mesh}$ ), as well as the other micronutrients, was supplied by Roche Vitamins South Africa (Pty) Ltd, Johannesburg, South Africa and the ferrous bisglycinate (Ferrochel ${ }^{\circledR}$ ) by Albion Laboratories, Inc., Clearfield, UT, USA. The control wheat flour was not fortified with $\mathrm{Fe}$ or any of the other micronutrients. The three types of flour were packaged in colour-coded flour bags and sent to a local baker, who was 
Table 1. Amounts of micronutrients supplied by $120 \mathrm{~g}$ bread (four slices; $72 \mathrm{~g}$ flour)*

\begin{tabular}{|c|c|c|c|c|}
\hline \multirow[b]{2}{*}{ Micronutrient } & \multirow[b]{2}{*}{ Amount per day for $75 \mathrm{~d} \dagger$} & \multirow[b]{2}{*}{ Amount per day for $62 \mathrm{~d} \ddagger$} & \multicolumn{2}{|c|}{$\begin{array}{l}\text { Average amount per } \\
\text { intervention day }\end{array}$} \\
\hline & & & Amount & $\%$ RDA§ \\
\hline $\mathrm{Fe}(\mathrm{mg})$ & 2.52 & 5.04 & 3.66 & $40 \cdot 7$ \\
\hline $\mathrm{Zn}(\mathrm{mg})$ & 1.08 & $2 \cdot 16$ & 1.57 & $24 \cdot 2$ \\
\hline Vitamin $A(\mu g R E)$ & $128 \cdot 6$ & $257 \cdot 2$ & $186 \cdot 8$ & $37 \cdot 4$ \\
\hline Thiamine (mg) & 0.14 & 0.28 & 0.2 & $26 \cdot 7$ \\
\hline Riboflavin (mg) & 0.13 & 0.26 & 0.19 & $25 \cdot 3$ \\
\hline Niacin $(\mathrm{mg})$ & 1.71 & 3.41 & 2.48 & $24 \cdot 8$ \\
\hline Pyridoxine (mg) & 0.19 & 0.38 & 0.28 & $35 \cdot 0$ \\
\hline Folic acid $(\mu \mathrm{g})$ & 103 & 206 & 150 & $60 \cdot 0$ \\
\hline \multicolumn{5}{|c|}{$\begin{array}{l}\text { RE, retinol equivalents. } \\
\text { *Amounts in addition to the } \pm 1.8 \mathrm{mg} \text { Fe naturally present in } 120 \mathrm{~g} \text { brown bread (Langenhoven et al. 1991). } \\
\text { † Amounts prescribed by the national food fortification programme of the South African Department of Health for the fortification } \\
\text { of wheat flour (Department of Health, 2003). }\end{array}$} \\
\hline
\end{tabular}

contracted to bake and deliver the bread to the school on a daily basis during the school week.

\section{Quality control}

To enhance quality control, the procedures followed by the baker, especially in terms of keeping the three types of flour and bread apart throughout the baking process, were observed and recorded in detail by a member of the research team, who visited the bakery unannounced twice during the intervention period. In addition, bread samples were sent to the Council for Scientific and Industrial Research (Pretoria, South Africa) once a month for analysis of Fe content (Table 2).

\section{Measurements}

Biochemical indices. Blood $(5 \mathrm{ml})$ was obtained by antecubital venepuncture. All blood samples were collected between 08.30 and 13.00 hours, and the three treatment groups were distributed evenly over this period. Care was taken to protect the blood from direct sunlight. Hb was measured in the field by means of the direct cyanmethaemoglobin method, using Drabkin's solution and a standard photometer. The rest of the blood was centrifuged and the serum stored at $-80^{\circ} \mathrm{C}$ until analysed. Serum ferritin was determined by an immunoradiometric assay (Ferritin MAb Solid Phase Component System; ICN Pharmaceuticals, Orangeburg, NY, USA), using an Auto Gamma 500C counting system

Table 2. Analysed iron content of the two types of fortified breads (mg/ $120 \mathrm{~g}$ bread)*

(Mean values and standard deviations)

\begin{tabular}{llllll}
\hline & \multicolumn{2}{c}{$\begin{array}{c}\text { Electrolytic Fe } \\
\text { group }\end{array}$} & & \multicolumn{2}{c}{$\begin{array}{c}\text { Ferrous bisglyci- } \\
\text { nate group }\end{array}$} \\
\cline { 2 - 3 } & Mean & SD & & Mean & SD \\
\hline $\begin{array}{c}\text { First period of 4.5 months } \\
\text { (average of five batches) }\end{array}$ & 4.94 & 0.54 & & 4.85 & 0.59 \\
$\begin{array}{c}\text { Second period of 3 months } \\
\text { (average of three batches) }\end{array}$ & 8.77 & 0.93 & & 8.38 & 1.53 \\
\hline
\end{tabular}

*Values include the Fe naturally present in bread.
(United Technologies Packard, IL, USA). Serum Fe and transferrin were determined spectrophotometrically with a Technicon RA-1000 automated system, using colorimetric and turbidimetric methods from Bayer Corporation (Tarrytown, NY, USA), respectively; these values were then used to calculate transferrin saturation. C-reactive protein was determined with a turbidimetric method from Bayer Corporation and measured spectrophotometrically with a Technicon RA-1000 automated system. Serum retinol was determined (under dimmed light) by reversed-phase HPLC, based on the method described by Catignani and Bieri (1983).

Anthropometry. Weight was measured (in light clothing) to the nearest $0.05 \mathrm{~kg}$, and height (without shoes) to the nearest $0.1 \mathrm{~cm}$. Height-for-age, weight-for-age and weight-for-height were expressed as $Z$ scores, using the National Center for Health Statistics median as reference (Hamill et al. 1979). The birth date of each child was obtained from the school register.

\section{Statistical analyses}

Data were analysed using the SPSS for Windows program (SPSS Inc., Chicago, IL, USA, version 11.0). Hb data were analysed on an intention-to-treat basis. For serum ferrritin, serum Fe and transferrin saturation, however, five children with infection (C-reactive protein $\geq 10 \mathrm{mg} / \mathrm{l}$ ) at baseline or follow-up were excluded from the analyses. The paired $t$ test was used to compare pre- and post-intervention values within each treatment group. To estimate treatment effects an ANOVA was done on the measurement after the intervention period, as well as an analysis of covariance using baseline measurement and gender as covariates. Values of $P<0.05$ were considered statistically significant. Because only children with low serum ferritin concentrations $(<20 \mu \mathrm{g} / \mathrm{l})$ were included in the study, serum ferritin values were normally distributed and $\log$ transformation before analysis was therefore not necessary.

\section{Results}

Of the 160 children who were randomised for treatment, 153 completed the trial. Reasons for dropping out were leaving the area $(n 4)$, failure to obtain blood from the child at the follow-up assessment ( $n$ 1), withdrawal of parental consent $(n 1)$ 
and a follow-up $\mathrm{Hb}$ value $<90 \mathrm{~g} / \mathrm{l}(n$ 1). The trial profile is given in Fig. 1. Mean compliance (defined as the actual number of bread slices consumed, expressed as a percentage of the total number of slices provided over the trial period) was $96.5 \%, 95.7 \%$ and $95.3 \%$ in the control, electrolytic $\mathrm{Fe}$ and ferrous bisglycinate groups, respectively. Absence from school was the main reason for non-compliance.

Baseline characteristics of the control and intervention groups are given in Table 3 . The three groups were similar with regard to age, height, weight, $\mathrm{Fe}, \mathrm{Hb}$ and vitamin A status. There were slightly more boys in the control group than in the other two groups. Almost $30 \%$ of the children were stunted or underweight, yet very few were anaemic $(7.5 \%)$ and almost none were vitamin A-deficient $(<1 \%)$. The mean serum retinol of the study population was 35.5 (SD 7.6) $\mu \mathrm{g} / \mathrm{dl}$.

\section{Intervention effects}

The $\mathrm{Hb}$ concentrations in the control and two intervention groups at baseline and after 7.5 months of intervention are shown in Table 4. There was a significant increase from baseline to follow-up in the ferrous bisglycinate group only, with the intervention effect being significant when gender and the baseline $\mathrm{Hb}$ measurement were adjusted for. The increase in $\mathrm{Hb}$ in the ferrous bisglycinate group was also significant compared with the electrolytic Fe group, and the intervention effect four times that in the electrolytic Fe group. Table 5 shows the serum $\mathrm{Fe}$ and transferrin saturation values before and after the intervention. Significant treatment effects for both serum $\mathrm{Fe}$ and transferrin saturation were observed in the ferrous bisglycinate group, while the electrolytic Fe group showed no significant response. Serum ferritin concentrations at the beginning and end of the intervention period are shown in Table 6 . There was no significant intervention effect for serum ferritin in either the ferrous bisglycinate or electrolytic Fe group, and neither when gender and serum ferritin at baseline were adjusted for.

\section{Discussion}

The choice of $\mathrm{Fe}$ compound in a fortification programme will determine whether or not the Fe-deficient sector of a population will benefit from that programme. Trials validating the efficacy of different $\mathrm{Fe}$ fortification compounds are therefore important, and should be a step prior to the implementation of such programmes. Results of the present randomised controlled trial showed that ferrous bisglycinate as fortificant in brown bread performed better than electrolytic $\mathrm{Fe}$, in terms of improved $\mathrm{Hb}$ and circulating Fe levels, in a group of Fe-deficient school children over a period of 7.5 months. Significant intervention effects were observed for $\mathrm{Hb}$, serum $\mathrm{Fe}$ and transferrin saturation in the ferrous bisglycinate group, while the electrolytic Fe group showed no significant intervention effects for any of the variables measured.

Finding the ideal Fe fortification compound is not easy and usually represents a compromise between factors such as bioavailability, potential for causing organoleptic problems and cost (Dary, 2002). While ferrous bisglycinate has a bioavailability two to four times that of ferrous sulfate (Olivares et al. 1997; Bovell-Benjamin et al. 2000; Layrisse et al. 2000), it is expensive. A recent cost analysis carried out by a SUSTAIN Task Group showed the cost of ferrous bisglycinate, taking bioavailability into account, to be between 7.2 and 18.5 times that of ferrous sulfate (Moore et al. 2004). Wider usage and increased competition in future may, however, reduce cost.

Furthermore, concerns had been raised regarding the tendency of ferrous bisglycinate to cause lipid peroxidation and rancidity in maize meal (Bovell-Benjamin et al. 1999a). These changes can, however, be prevented by the addition of an antioxidant (Bovell-Benjamin et al. 1999a), and it has been shown that ferrous bisglycinate-fortified maize meal porridge was acceptable to both toddlers and their mothers, with or without the addition of the antioxidant (Bovell-Benjamin et al. 1999b). In the present study, no obvious organoleptic changes were noticed in the bread fortified with ferrous bisglycinate; the bread looked and tasted the same as the control and electrolytic Fe-fortified breads. However, sensory tests were not carried out and the fortified flour was not stored for longer than 1 month at a time. Further investigation into the stability of wheat flour fortified with ferrous bisglycinate is therefore needed.

Electrolytic Fe, while being relatively inexpensive (costing half as much as ferrous sulfate for the same amount of Fe; Hurrell, 1997) and causing few organoleptic problems, has an estimated bioavailability of approximately only half that of ferrous sulfate. This estimate is based on $\mathrm{Hb}$ repletion studies in rats (Hurrell et al.

Table 3. Baseline characteristics of the study children

(Mean values and standard deviations or percentages)

\begin{tabular}{|c|c|c|c|c|c|c|}
\hline & \multicolumn{2}{|c|}{ Control ( $n$ 53) } & \multicolumn{2}{|c|}{$\begin{array}{l}\text { Electrolytic } \\
\mathrm{Fe}(n 53)\end{array}$} & \multicolumn{2}{|c|}{$\begin{array}{c}\text { Ferrous bisglyci- } \\
\text { nate }(n 54)\end{array}$} \\
\hline & Mean & SD & Mean & SD & Mean & SD \\
\hline Age (years) & 7.96 & 0.95 & 7.90 & $1 \cdot 12$ & $7 \cdot 87$ & $1 \cdot 12$ \\
\hline Male (\%) & $64 \cdot 2$ & & $49 \cdot 1$ & & $46 \cdot 3$ & \\
\hline Stunted $(\%)^{*}$ & $28 \cdot 3$ & & $24 \cdot 5$ & & $27 \cdot 8$ & \\
\hline Underweight $(\%) \dagger$ & $28 \cdot 3$ & & $26 \cdot 4$ & & $27 \cdot 8$ & \\
\hline Wasted (\%)‡ & $3 \cdot 8$ & & 5.9 & & $7 \cdot 7$ & \\
\hline Serum ferritin $(\mu \mathrm{g} / \mathrm{l})$ & 11.5 & $4 \cdot 7$ & $11 \cdot 7$ & $5 \cdot 7$ & $11 \cdot 2$ & $5 \cdot 0$ \\
\hline $\mathrm{Hb}(\mathrm{g} / \mathrm{l})$ & $126 \cdot 7$ & 7.5 & $125 \cdot 9$ & $9 \cdot 3$ & $126 \cdot 7$ & $8 \cdot 2$ \\
\hline Vitamin A deficiency: serum retinol $<20 \mu \mathrm{g} / \mathrm{dl}(\%) \S$ & 0 & & 0 & & 1.9 & \\
\hline
\end{tabular}

${ }^{\star}$ Height-for-age $Z$ score $<-2$ SD of the National Center for Health Statistics median.

† Weight-for-age $Z$ score $<-2$ SD of the National Center for Health Statistics median.

$\ddagger$ Weight-for-height $Z$ score $<-2$ SD of the National Center for Health Statistics median.

$\S 1 \mu \mathrm{g} / \mathrm{dl}=0.035 \mu \mathrm{mol} / \mathrm{l}$. 
Table 4. $\mathrm{Hb}$ concentrations before and after 7.5 months of intervention

(Mean values and standard deviations except for intervention effects)

\begin{tabular}{|c|c|c|c|c|c|c|}
\hline & \multicolumn{2}{|c|}{ Control ( $n$ 51) } & \multicolumn{2}{|c|}{$\begin{array}{l}\text { Electrolytic Fe } \\
\qquad(n 53)\end{array}$} & \multicolumn{2}{|c|}{$\begin{array}{c}\text { Ferrous bisglyci- } \\
\text { nate }(n \text { 49) }\end{array}$} \\
\hline & Mean & SD & Mean & SD & Mean & SD \\
\hline \multicolumn{7}{|l|}{$\mathrm{Hb}(\mathrm{g} / \mathrm{l})$} \\
\hline Baseline & 126.8 & 7.6 & 125.9 & $9 \cdot 3$ & $126 \cdot 2$ & $8 \cdot 3$ \\
\hline 7.5 months & 127.5 & 7.4 & $127 \cdot 1$ & 7.5 & $129 \cdot 3 \S$ & 7.5 \\
\hline Change $^{\star}$ & 0.7 & $5 \cdot 3$ & $1 \cdot 2$ & $6 \cdot 8$ & $3 \cdot 1$ & $5 \cdot 1$ \\
\hline \multicolumn{7}{|l|}{ Intervention effect $\dagger$} \\
\hline Crude & & & -0.4( & 2.5) & $1.8(-$ & 4.7) \\
\hline Adjusted for gender and baseline measurement & & & 0.6 & 2.6) & $2.6(0$ & 6)\|, १ \\
\hline
\end{tabular}

* Mean change from baseline to follow-up.

$\dagger$ Intervention effect = difference $(95 \% \mathrm{Cl})$ in estimated marginal means at follow-up between intervention and control group.

$\S$ Mean value was significantly different compared with baseline (paired $t$ test): $P=0.001$.

\| Significant effect compared with control (analysis of covariance): $P=0.013$.

I Significant effect compared with electrolytic $\mathrm{Fe}$ (analysis of covariance): $P=0.043$.

2002), and there are very few studies evaluating its effectiveness as fortificant in human populations. In the present study, no significant treatment effects were observed in the group consuming the bread fortified with electrolytic Fe for $137 \mathrm{~d}$ over a period of 7.5 months. The average amount of Fe ingested per intervention day was equivalent to the amount that would have been taken in if five to six slices of bread, fortified according to the South African food fortification regulations, had been consumed. The South African government based their decision to use electrolytic $\mathrm{Fe}$ in its fortification programme on the guidelines issued by SUSTAIN (2001a), which were interim recommendations and based on the information available at the time. SUSTAIN has since launched a comprehensive evaluation of the different elemental $\mathrm{Fe}$ powders in use today, and human efficacy trials are currently being carried out in the USA, Thailand and China (SUSTAIN, 2001b), the results of which will contribute towards the revision of these guidelines. The results of the present study will also contribute towards this pool of information. Because of the high phytate content of maize it is very likely that our findings will be applicable to maize meal as well.

Our study was carried out in Fe-deficient children $(72 \%$ with serum ferritin $<15 \mu \mathrm{g} / \mathrm{l}$ ), but the prevalence of anaemia was low. The significant increase in $\mathrm{Hb}$ in the ferrous bisglycinate group, however, suggests that the $\mathrm{Hb}$ status of these children was still not optimal. The fact that there was no significant increase in serum ferritin compared with the control in either group, despite low initial concentrations, suggests that the level and/or duration of the fortification was probably sufficient to improve $\mathrm{Hb}$ status and increase circulating Fe levels, but may not have been enough to have had a significant impact on Fe stores as well. The high serum retinol concentrations encountered in this study population (due to a high intake of organ meat; data to be published elsewhere) may also have contributed to the small response in serum ferritin by resulting in the $\mathrm{Fe}$, taken in through the intervention, being optimally utilised for haematopoiesis; the results of several studies suggest that vitamin A may be necessary for the mobilisation of $\mathrm{Fe}$ from

Table 5. Serum iron and transferrin saturation before and after 7.5 months of intervention

(Mean values and standard deviations except for intervention effects)

\begin{tabular}{|c|c|c|c|c|c|c|}
\hline & Mean & SD & Mean & SD & Mean & SD \\
\hline \multicolumn{7}{|l|}{ Serum Fe $(\mu \mathrm{mol} / \mathrm{l})^{*}$} \\
\hline Baseline & $9 \cdot 91$ & 3.42 & $9 \cdot 76$ & 3.75 & $9 \cdot 81$ & 3.32 \\
\hline 7.5 months & 9.43 & $2 \cdot 91$ & $9 \cdot 87$ & 4.08 & $10 \cdot 91$ & 3.49 \\
\hline Crude & & & \multicolumn{2}{|c|}{$0.44(-0.93,1.82)$} & \multicolumn{2}{|c|}{$1.49(0.05,2.92) \S$} \\
\hline Adjusted for baseline measurement & & & \multicolumn{2}{|c|}{$0.46(-0.93,1.84)$} & \multicolumn{2}{|c|}{$1.50(0.06,2.94) \|$} \\
\hline \multicolumn{7}{|l|}{ Transferrin saturation $(\%)^{*}$} \\
\hline Baseline & 15.43 & $5 \cdot 79$ & $15 \cdot 84$ & $5 \cdot 96$ & $15 \cdot 90$ & 5.48 \\
\hline 7.5 months & $14 \cdot 70$ & 5.04 & $16 \cdot 19$ & $7 \cdot 01$ & $17 \cdot 30$ & 5.57 \\
\hline Change & -0.73 & $6 \cdot 71$ & 0.35 & $8 \cdot 31$ & 1.39 & $6 \cdot 70$ \\
\hline
\end{tabular}

${ }^{*}$ Children with C-reactive protein $\geq 10 \mathrm{mg} / \mathrm{l}$ at baseline or follow-up excluded.

$\dagger$ Mean change from baseline to follow-up.

$\ddagger$ Intervention effect $=$ difference $(95 \% \mathrm{Cl})$ in estimated marginal means at follow-up between intervention and control group.

Significant effect compared with control (analysis of covariance): $\S P=0.043, \| P=0.041, \uparrow P=0.036,{ }^{\star \star} P=0.042$. 
Table 6. Serum ferritin before and after 7.5 months of intervention

(Mean values and standard deviations except for intervention effects)

\begin{tabular}{|c|c|c|c|c|c|c|}
\hline & \multicolumn{2}{|c|}{ Control ( $n 50)$} & \multicolumn{2}{|c|}{$\begin{array}{l}\text { Electrolytic } \\
\text { Fe }(n 53)\end{array}$} & \multicolumn{2}{|c|}{$\begin{array}{l}\text { Ferrous bisglyci- } \\
\text { nate }(n 45)\end{array}$} \\
\hline & Mean & SD & Mean & SD & Mean & SD \\
\hline \multicolumn{7}{|l|}{ Serum ferritin $\left(\mu \mathrm{g} / \mathrm{I}^{*}\right.$} \\
\hline Baseline & $11 \cdot 29$ & 4.75 & 11.66 & $5 \cdot 70$ & $10 \cdot 90$ & $5 \cdot 21$ \\
\hline 7.5 months & $11 \cdot 72$ & 4.07 & $13 \cdot 22$ & $6 \cdot 28$ & $12 \cdot 18$ & $5 \cdot 24$ \\
\hline Change & 0.43 & 5.09 & 1.56 & $6 \cdot 98$ & $1 \cdot 28$ & $6 \cdot 60$ \\
\hline \multicolumn{7}{|l|}{ Intervention effect $\ddagger$} \\
\hline Crude & & & 1.50( & $3.56)$ & 0.46 & 2.61) \\
\hline Adjusted for gender and baseline measurement & & & 1.45( & $3.53)$ & 0.63 & $2 \cdot 78)$ \\
\hline
\end{tabular}

${ }^{*}$ Children with C-reactive protein $\geq 10 \mathrm{mg} / \mathrm{l}$ at baseline or follow-up excluded.

$\dagger$ Mean change from baseline to follow-up.

$\ddagger$ Intervention effect $=$ difference $(95 \% \mathrm{Cl})$ in estimated marginal means at follow-up between intervention and control group.

body stores (Mejía \& Chew, 1988; Bloem et al. 1990; Van Stuijvenberg et al. 1997; Muslimatun et al. 2001).

The bioavailability of ferrous bisglycinate has never been compared directly with that of electrolytic Fe. Extrapolating from studies comparing the bioavailability of either ferrous bisglycinate or electrolytic $\mathrm{Fe}$ with that of ferrous sulfate, however, it can be deduced that ferrous bisglycinate is absorbed four to eight times better than electrolytic Fe (Olivares et al. 1997; Bovell-Benjamin et al. 2000; Layrisse et al. 2000; Hurrell et al. 2002). In our study the intervention effect in terms of $\mathrm{Hb}$ for ferrous bisglycinate was four times that of electrolytic Fe.

Ferrous bisglycinate, because of its high bioavailability and relative low reactivity, especially in milk products (Allen, 2002), appears to be an ideal Fe fortificant. Ferrous bisglycinate also has the advantage in that it is considered a 'natural' product (Hurrell, 2002). In addition, amino acid chelates have been reported to cause fewer losses of other vitamins in multivitamin mixtures compared with ferrous sulfate (Marchetti et al. 2000). The high cost of ferrous bisglycinate may, however, limit the feasibility of it being used in national fortification programmes, especially in developing countries, although it could in future become a viable option if costs come down and the issues around organoleptic problems are resolved. Another $\mathrm{Fe}$ chelate that can be considered an attractive option for use in fortification programmes is NaFeEDTA. NaFeEDTA has a bioavailability similar to that of ferrous bisglycinate but is less expensive, costing approximately only half as much (Moore et al. 2004). Its potential as fortificant has been confirmed in several fortification trials and in vehicles such as curry powder (Ballot et al. 1989), sugar (Viteri et al. 1995), fish sauce (Thuy et al. 2004) and soya sauce (Chen et al. 2005). There is currently a need for fortification-grade NaFeEDTA to become more widely available and more affordable, and this will in all likelihood further bring down the cost (Bothwell \& MacPhail, 2004).

In conclusion, in the present study which examined the efficacy of ferrous bisglycinate and electrolytic $\mathrm{Fe}$ as fortificants in brown bread among Fe-deficient school children, ferrous bisglycinate resulted in improved $\mathrm{Hb}$ and circulating $\mathrm{Fe}$ levels, while the electrolytic $\mathrm{Fe}$ group showed no response. Our study adds to the currently very limited pool of randomised controlled trials measuring the effect of electrolytic $\mathrm{Fe}$ and ferrous bisglycinate as fortificants on $\mathrm{Fe}$ status in human populations. The high bioavailability and relatively low reactivity of ferrous bisglycinate in foods, especially in milk products, makes this compound an attractive option for fortification. Its current high cost at this stage may, however, limit its usefulness at programme level, and alternative options that are as bioavailable but less expensive, e.g. NaFeEDTA, should also be explored.

\section{Acknowledgements}

We thank Martelle Marais, Eldrich Harmse, Serene Schoeman and De Wet Marais for their excellent technical support in the field and laboratory; the headmaster, staff and pupils of Hantam Primary School for their friendly co-operation; the field workers from the community who prepared and distributed the sandwiches; and Premier Milling and Baking for supplying the flour. The study was partially supported by a grant from CELANEM and Albion Laboratories, Inc.

\section{References}

Allen LA (2002) Advantages and limitations of iron amino acid chelates as iron fortificants. Nutr Rev 60, Suppl., S18-S21.

Ballot DE, MacPhail AP, Bothwell TH, Gillooly M \& Mayet FG (1989) Fortification of curry powder with $\mathrm{NaFe}(\mathrm{III}) \mathrm{EDTA}$ in an iron-deficient population: report of a controlled iron-fortification trial. Am J Clin Nutr 49, $162-169$.

Bloem MW, Wedel M, Van Agtmaal EJ, Speek AJ, Saowakontha S \& Schreurs WHP (1990) Vitamin A intervention: short-term effects of a single, oral, massive dose on iron metabolism. Am J Clin Nutr 51, 76-79.

Bothwell TH \& MacPhail AP (2004) The potential role of NaFeEDTA as an iron fortificant. Int J Vitam Nutr Res 74, 421-434.

Bovell-Benjamin AC, Allen LH, Frankel EN \& Guinard J-X (1999a) Sensory quality and lipid oxidation of maize porridge as affected by iron amino acid chelates and EDTA. J Food Sci 64, 371-376.

Bovell-Benjamin AC, Allen LH \& Guinard J-X (1999b) Toddlers' acceptance of whole maize meal porridge fortified with ferrous bisglycinate. Food Qual Preference 10, 123-128.

Bovell-Benjamin AC, Viteri FE \& Allen LH (2000) Iron absorption from ferrous bisglycinate and ferric trisglycinate in whole maize is regulated by iron status. Am J Clin Nutr 71, 1563-1569.

Catignani GL \& Bieri JG (1983) Simultaneous determination of retinol and $\alpha$-tocopherol in serum or plasma by liquid chromatography. Clin Chem 29, 708-712. 
Chen J, Zhao X, Zhang X, et al. (2005) Studies on the effectiveness of NaFeEDTA-fortified soy sauce in controlling iron deficiency: a population-based intervention trial. Food Nutr Bull 26, 177-186.

Cook JD \& Reusser M (1983) Iron fortification: an update. Am J Clin Nutr 38, 648-659.

Dary O (2002) Staple food fortification with iron: a multifactorial decision. Nutr Rev 60, Suppl., S34-S41.

Department of Health (2003). Regulations relating to the fortification of certain foodstuffs. http://www.doh.gov.za/docs/regulations/2003/ ffortification.html.

Food and Nutrition Board, Institute of Medicine (2001) Dietary Reference Intakes for Vitamin A, Vitamin K, Arsenic, Boron, Chromium, Copper, Iodine, Iron, Manganese, Molybdenum, Nickel, Silicon, Vanadium, and Zinc. Washington, DC: National Academy Press.

Hallberg L, Brune M \& Rossander L (1989) Iron absorption in man: ascorbic acid and dose-dependent inhibition by phytate. Am J Clin Nutr 49, 140-144.

Hamill PVV, Drizd TA, Johnson CL, Reed RB, Roche AF \& Moore WM (1979) Physical growth: National Center for Health Statistics percentiles. Am J Clin Nutr 32, 607-629.

Hurrell RF (1997) Preventing iron deficiency through food fortification. Nutr Rev 55, 210-222.

Hurrell RF (2002) Fortification: overcoming technical and practical barriers. J Nutr 132, Suppl., S806-S812.

Hurrell R, Bothwell T, Cook JD, et al. (2002) The usefulness of elemental iron for cereal flour fortification: a SUSTAIN Task Force report. Nutr Rev 60, 391-406.

Jeppsen RB (2001) Toxicology and safety of Ferrochel and other amino acid chelates. Arch Latinoam Nutr 51, Suppl. 1, 26-34.

Langenhoven ML, Kruger M, Gouws E \& Faber M (1991) MRC Food Composition Tables, 3rd ed, Parow, South Africa: Medical Research Council.

Layrisse M, García-Casal MN, Solano L, Barón MA, Arguello F, Llovera D, Ramírez J, Leets I \& Tropper E (2000) Iron bioavailability in humans from breakfasts enriched with iron bis-glycine chelate, phytates and polyphenols. J Nutr 130, 2195-2199.

Marchetti M, Ashmead H DeW, Tossani N, Marchetti S \& Ashmead SD (2000) Comparison of the rates of vitamin degradation when mixed with metal sulphates or metal amino acid chelates. J Food Compost Anal 13, 875-884.

Mejía LA \& Chew F (1988) Hematological effect of supplementing anemic children with vitamin A alone and in combination with iron. Am J Clin Nutr 48, 595-600.
Moore W, Grant F, Kratky Z, Bothwell T, Rodenstein M, Streekstra H, Turner E \& Wreesmann C (2004) A model for calculating the cost of employing iron absorption enhancement strategies in fortification programs. Int J Vitam Nutr Res 74, 463-466.

Muslimatun S, Schmidt MK, Schultink W, West CE, Hautvast JGAJ, Gross R \& Muhilal (2001) Weekly supplementation with iron and vitamin A during pregnancy increases hemoglobin concentration but decreases serum ferritin concentration in Indonesian pregnant women. J Nutr 131, 85-90.

Olivares M, Pizarro F, Pineda O, Name JJ, Hertrampf E \& Walter T (1997) Milk inhibits and ascorbic acid favors ferrous bis-glycine chelate bioavailability in humans. J Nutr 127, 1407-1411.

Siegenberg D, Baynes RD, Bothwell TH, Macfarlane BJ, Lamparelli RD, Car NG, MacPhail P, Schmidt U, Tal A \& Mayet F (1991) Ascorbic acid prevents the dose-dependent inhibitory effects of polyphenols and phytates on nonheme-iron absorption. Am J Clin Nutr 53, 537-541.

SUSTAIN (2001a). Guidelines for iron fortification of cereal food staples. http://www.sustaintech.orgpublications/pubm7.pdf.

SUSTAIN (2001b). Evaluation of the bioavailability of elemental iron powders used for food fortification. A comprehensive research effort organized by SUSTAIN. http://www.sustaintech.orgpublications/ pubm1.pdf.

Swain JH, Newman SM \& Hunt JR (2003) Bioavailability of elemental iron powders to rats is less than bakery-grade ferrous sulphate and predicted by iron solubility and particle surface area. J Nutr 133, 3546-3552.

Thuy PV, Berger J, Davidson L, Khan NC, Lam NT, Cook JD, Hurrell RF \& Khoi HH (2004) Regular consumption of NaFeEDTA-fortified fish sauce improves iron status and reduces the prevalence of anemia in anemic Vietnamese women. Am J Clin Nutr 78, 284-290.

Van Stuijvenberg ME, Kruger M, Badenhorst CJ, Mansvelt EPG \& Laubscher JA (1997) Response to an iron fortification programme in relation to vitamin A status in 6-12-year-old school children. Int $J$ Food Sci Nutr 48, 41-49.

Van Stuijvenberg ME, Kvalsvig JD, Faber M, Kruger M, Kenoyer DG \& Benadé AJS (1999) Effect of iron-, iodine- and $\beta$-carotene-fortified biscuits on the micronutrient status of primary school children: a randomized controlled trial. Am J Clin Nutr 69, 497-503 [erratum in Am J Clin Nutr (1999) 69, 1294].

Viteri FE, Alvarez E, Batres R, Torún B, Pineda O, Mejía LA \& Sylvi J (1995) Fortification of sugar with iron sodium ethylenediaminotetraacetate (FeNaEDTA) improves iron status in semirural Guatemalan populations. Am J Clin Nutr 61, 1153-1163. 